\title{
Dawsonite as a Daughter Mineral in Hydrothermal Fluid Inclusions
}

\author{
Raymond M. Coveney and Winliam C. KetluY \\ Department of Geology and Mineralogy, The University of Michigan, Ann Arbor, \\ Michigan 48104, USA
}

Received July 19, 1971

\begin{abstract}
Traces of dawsonite $\left(\mathrm{NaAlCO}_{3}(\mathrm{OH})_{2}\right)$ are extremely common as a daughter product in fluid inclusions in gold-quartz veins and altered wallrock of the Oriental mine, Alleghany district, California. A very similar daughter salt occurs in hydrothermal inclusions in quartz from 19 other mining localities of worldwide distribution.

Vein fluids of the Oriental mine were probably $\mathrm{CO}_{2}$-rich sodium bicarbonate brines that contained at least 1 weight percent dissolved aluminum. These fluids precipitated quartz and oligoclase in the veins and adjacent altered rocks. The precipitation of dawsonite rather than albite or oligoclase in the cooled inclusion brines suggests either that sodic plagioclase gives way to dawsonite plus quartz as the stable pair at low temperatures or that the dawsonite is a metastable daughter mineral. The rarity of dawsonite as a separate vein mineral or alteration product at the Oriental mine and elsewhere is attributed to its high solubility under normal conditions of mineralization.

Dawsonite contributes $190 \mathrm{ppm}$ or more to the aluminum content of some Oriental mine quartz. Large errors would result if the dawsonite were overlooked and the aluminum geothermometer of Dennen et al. (1970) were applied to this quartz. The combination of high primary inclusion filling temperatures and very low aluminum contents of optically clear quartz indicate that major revisions are needed in the published thermometer curve.
\end{abstract}

\section{Introduction}

Since its initial discovery on the McGill University campus in 1862 (Harrington, 1874), dawsonite $\left(\mathrm{NaAlCO}_{3}(\mathrm{OH})_{2}\right)$ has been found in only eleven other widely scattered world localities. These occurrences have been fully described by Palache and others (1951), Hay (1963), Michele and others (1965), Smith and Milton (1966), Loughnan and See (1967) and Goldberry and Loughnan (1970). From this literature, it appears that dawsonite can form by direct precipitation from low temperature hydrothermal solutions or by attack of $\mathrm{Na}_{2} \mathrm{CO}_{3^{-}}$or $\mathrm{NaHCO}_{3}$-rich solutions on aluminous silicates during diagenesis and weathering in highly saline environments. The mineral is extremely abundant only in the Eocene Green River Formation oil shales of the Piceance Creek basin of northwestern Colorado (Milton and Eugster, 1959; Smith and Milton, 1966) where its occurrence has drawn interest as a potential source of aluminum in economic quantities. Substantial but lesser amounts are also known to occur in the Permian Greta Coal Measures (Loughnan and See, 1967) and the Permian Berry Formation (Goldberry and Loughnan, 1970) of the Sydney Basin in New South Wales. In an interesting occurrence described by Hay (1963), dawsonite is found in highly saline soils developed on nepheline syenite tuffs exposed in the Olduvai Gorge in Tanzania, East Africa. In its seven other reported occurrences, dawsonite is 
present in only minor quantities and there is a tendency, still, to regard the mineral as rare.

Present studies show that dawsonite can form as a daughter salt ${ }^{1}$ in fluid inclusions in hydrothermal quartz and suggest that, as such, the mineral may be extremely common in trace amounts in many ore deposits. The dawsonite has been positively identified in gold-quartz veins of the Oriental mine, Alleghany district, California and is tentatively recorded in ores of 19 other mines or mining camps of worldwide distribution. These unusual occurrences of dawsonite shed some light upon conditions favoring its precipitation, and have important implications with regard to use of the aluminum content of quartz as a geologic thermometer.

\section{Dawsonite of the Oriental Mine, Alleghany District, California}

In their comprehensive study of the gold ores of the Alleghany district in California, Ferguson and Gannet (1932, p. 45) observed clusters of very minute fibers as common daughter products in fluid inclusions of the vein quartz. They suspected that this mineral was sericite, but the crystals were too small for positive identification. During recent investigations of the Oriental mine, Coveney (1971) found what is presumably this same mineral in countless fluid inclusions in nearly all of 20 quartz crystals prepared for inclusion study.

This daughter mineral has a highly distinctive appearance, occurring as sheaves or radial aggregates of hairlike crystals within the water-rich phase of the fluid inclusions (Fig. 1). The aggregates are best described as resembling tiny sea urchins. The individual crystals are typically 5 to 20 microns long and about 1 to 3 microns thick, but some as large as $200 \times 5$ microns were seen. The crystals are strongly anisotropic and, in spite of their small size, are easily spotted under crossed polars when the surrounding quartz is turned to extinction (Fig. 1 C). In samples with abundant dawsonite, we have counted between 13 and 38 separate aggregates per cubic millimeter (!) of the quartz and many of the smallest and most numerous aggregates were not included in these counts.

One of the largest aggregates seen was extracted from its fluid inclusion by drilling into the quartz with a diamond dental bit. The tiny sample so obtained gave an excellent X-ray powder pattern with 21 lines matching (in both position and intensity) the previously published standards for dawsonite (Mandarino and Harris, 1965). No foreign lines appeared in this pattern. Two other samples of dawsonite were X-rayed while still enclosed in tiny chips of quartz. These chips were not rotated during exposure and hence the quartz reflections were spots and easily distinguished from continuous lines given by the fine-grained daughter salt. Five of the strongest dawsonite lines appeared in one of these powder patterns, and four in the other.

Quantitative optical properties of the dawsonite are difficult to measure while the small and twisted fibers are still enclosed in quartz. The peculiar aggregate structure and strong birefringence $(\sim 0.13)$ are the most distinctive properties. While in the inclusions, the dawsonite has a distinct, but pale, green or tan tint, but is not discernably pleochroic. It shows strong, positive relief against the

1 A mineral precipitated from inclusion fluids during cooling. 

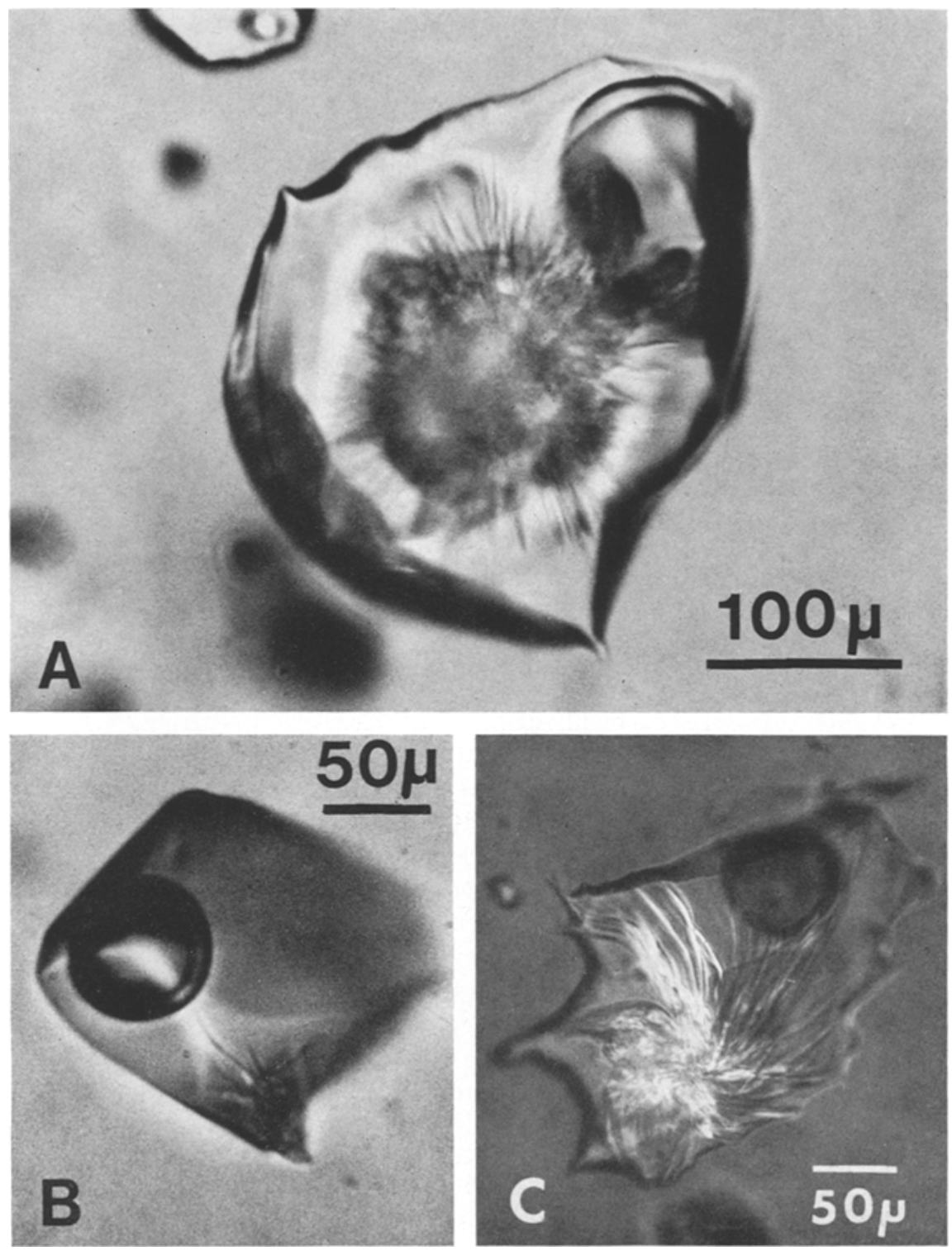

Fig. 1A-C. Dawsonite-bearing fluid inclusions in vein quartz of the Oriental mine, Alleghany district, California. A Typical radial aggregate of dawsonite within water-rich, liquid phase of inclusion. Sample from 700 level on Oriental vein. B Small cluster of dawsonite crystals in inclusion that shows distinct rim of liquid $\mathrm{CO}_{2}$ around vapor phase. Sample from 2300 level on Carrolson vein. C Strongly birefringent dawsonite fibers. Analyzer is in, but rotated about $10^{\circ}$ clockwise from crossed position. Sample from 1900 level on Carrolson vein

enclosing inclusion liquid, and this relief is the same or very close to that of the quartz host against this same fluid. Individual fibers display parallel extinction, although it is difficult to find isolated, straight crystals on which to test this 
property; some twisted aggregates give an erroneous impression of inclined extinction. When extracted from the inclusions, the dawsonite appears silky and white in air and is transparent and colorless in oil. The crystals have a refractive index of 1.54 measured parallel to their elongation. The extracted dawsonite effervesces and dissolves quickly in cold, concentrated HCl.

The dawsonite occurs in primary fluid inclusions both in the quartz of the main veins and of veinlets penetrating adjacent altered granite. The vein quartz is about the same age as intergrown arsenopyrite, pyrite, sphalerite, and native gold. The dawsonite was also seen as a daughter mineral in one sample of oligoclase $\left(A n_{10}\right)$ from the altered granite, but in quantities insufficient for X-ray analysis. Ankerite and calcite were identified as additional daughter salts in the vein quartz by $\mathrm{X}$-ray analysis. These minerals may occur in the same quartz crystals with dawsonite, but not in the same fluid inclusions. In single crystals of the vein quartz, dawsonite tends to occur in inclusions in inner, older growth zones and the ankerite or calcite in outer, younger zones. A twinned crystal of oligoclase (?) was seen as a daughter salt in a single fluid inclusion in quartz from the altered granite; this mineral, though common as an alteration product of the granite, is extremely rare as a daughter salt in any of the hydrothermal minerals. Dawsonite has the reverse tendencies, being extremely common as a daughter mineral but virtually unknown as a normal vein or alteration mineral. The significance of these observations will be discussed in later pages.

All of the dawsonite-bearing fluid inclusions are rich in $\mathrm{CO}_{2}$ and most shown a distinct rim of liquid $\mathrm{CO}_{2}$ around the vapor phase at room temperature (Fig. 1). Upon slight heating, this liquid $\mathrm{CO}_{2}$ and the vapor homogenize (by expansion of the liquid) at temperatures between 28.2 and $30.1{ }^{\circ} \mathrm{C}$, just below the critical temperature of $\mathrm{CO}_{2}$ at $31{ }^{\circ} \mathrm{C}$. From these data and the measured volume of the homogenized $\mathrm{CO}_{2}$-rich fluid, it is inferred that these inclusions contain approximately 23 mole percent $\mathrm{CO}_{2}$ and have an internal $\mathrm{CO}_{2}$ pressure on the order of 70 bars (Kennedy, 1954).

Freezing points of the water-rich liquid in the inclusions range from -2.5 to $-0.1{ }^{\circ} \mathrm{C}$ suggesting equivalent $\mathrm{NaCl}$ contents on the order of 3.5 weight percent or less. However, no halite cubes occur in the inclusions and there is no direct evidence of any chlorine in these fluids. From present evidence, the original mineralizing fluid could well have been a sodium bicarbonate brine saturated in $\mathrm{SiO}_{2}$ and highly charged with dissolved $\mathrm{CO}_{2}$.

The filling temperatures of the dawsonite-bearing fluid inclusions are between 201 and $233^{\circ} \mathrm{C}$. These, of course, are only minimum growth temperatures for the quartz and are subject to positive corrections for total pressure at the time of mineralization. From other data soon to be published (Coveney, 1971), it appears that true growth temperatures of the quartz were somewhere between about 220 and $500{ }^{\circ} \mathrm{C}$. The dawsonite in these inclusions shows no sign of redissolving during the filling temperature determinations and this puzzling behavior is discussed in later pages.

\section{Other Dawsonite (?) Occurrences}

Prior to identification of the dawsonite in ores of the Oriental mine, a daughter mineral with the same peculiar properties had been seen in hydrothermal quartz 
Table. Sources of quartz crystals containing dawsonite(?) as daughter salt in fluid inclusions

\begin{tabular}{ll}
\hline Locality & $\begin{array}{l}\text { Minerals } \\
\text { intergrown } \\
\text { with puartz }\end{array}$ \\
\hline 1. Araca mine, Bolivia & Cs, Wf \\
2. Belmont, Nevada & Py \\
3. Butte district, Montana & Py, En, Ce \\
4. Caracoles mine, Bolivia & Sl, Cs, Wf, Tm \\
5. Casapalea mine, Peru & - \\
6. Corina mine, Casapalca, Peru & Py, Sl \\
7. Four Metals mine, Patagonia, Arizona & $\mathrm{Sl}, \mathrm{Py}$ \\
8. Freiberg district, Saxony & $\mathrm{Po}$ \\
9. Gum Tree Claim, Idaho Springs, Colo. & $\mathrm{Sl}, \mathrm{Cp}, \mathrm{Py}$ \\
10. Idarado mine, Telluride, Colorado & $\mathrm{SI}$ \\
11. Llallagua mine, Bolivia & $\mathrm{Cs}$ \\
12. Mendota mine, Silver Plume, Colorado & $\mathrm{Sl}, \mathrm{Py}$ \\
13. New England, New South Wales & $\mathrm{Cs}$ \\
14. Schemnitz, Hungary & $\mathrm{Hm}, \mathrm{Sl}, \mathrm{Ga}, \mathrm{Cp}$ \\
15. Schlackenwald, Bohemia & $\mathrm{Cs}$ \\
16. Tras Cuarenta mine, Araca, Bolivia & $\mathrm{Wf}$ \\
17. Treverbyn, Cornwall district, England & $\mathrm{Cs}$ \\
18. Ward district, Colorado & $\mathrm{Wf}, \mathrm{Py}$ \\
19. Zinnwald, Bohemia & $\mathrm{Sc}$ \\
\hline
\end{tabular}

$\mathrm{Cs}=$ Cassiterite, $\mathrm{Cc}=$ Chalcocite, $\mathrm{Cp}=$ Chalcopyrite, $\mathrm{En}=$ Enargite, $\mathrm{Ga}=$ Galena, $\mathrm{Hm}=$ Hematite, $\mathrm{Po}=$ Pyrrhotite, $\mathrm{Py}=$ Pyrite, $\mathrm{Sc}=$ Scheelite, $\mathrm{Sl}=$ Sphalerite, $\mathrm{Tm}=$ Tourmaline, $\mathrm{Wf}=$ Wolframite.

from many other ore deposits. It was first noticed in quartz from several mining camps in the Bolivian tin-silver province by Kelly and Turneaure (1970) who tentatively and mistakenly identified it as some sodium-bearing silicate. Subsequently, Coveney (1968) sought and found what appeared to be the same mineral in inclusions in quartz from 15 other mines or mining districts of worldwide distribution. In all of these occurrences, the mineral displays the unusual radial aggregate structure and the same optical properties described for known dawsonite of the Oriental mine. In no case, however, have these other localities yielded sufficient dawsonite (?) for X-ray analysis and so these reported occurrences can only be regarded as tentative. The localities involved are listed in the Table along with the record of minerals intergrown with the quartz examined. Almost all of the quartz crystals studied were museum specimens for which the precise locations within the major mines or districts given are unknown. It should also be stressed that the dawsonite was sought almost exclusively in quartz, and so its occurence as a daughter salt in other minerals remains untested.

\section{Aluminum Content of Quartz as a Geologic Thermometer}

Dennen and his co-workers (1970) have proposed that the aluminum content of quartz formed in an aluminum-saturated environment is a linear and direct function of its depositional temperature. From analyses of natural and synthetic 
quartz of known or estimated formational temperature, they infer that the aluminum content varies from about $50 \mathrm{ppm}$ at $200{ }^{\circ} \mathrm{C}$ to roughly $150 \mathrm{ppm}$ at $573{ }^{\circ} \mathrm{C}$. The presence of dawsonite as a separate aluminous phase within the fluid inclusions in quartz has several important implications with regard to this proposed thermometer.

Rough estimates of the volume and number of dawsonite aggregates in one sample of quartz from the Oriental mine suggested that a rather large quantity of aluminum, on the order of $240 \mathrm{ppm}$, may be combined in this daughter mineral. Through the cooperation of Dr. William H. Dennen, more accurate figures were obtained by his spectographic analysis of several Oriental mine samples. Three samples were analyzed, all from a single quartz crystal about 1/2 inch in size. Polished plates of this crystal were broken into tiny chips and these were sorted under a binocular microscope into three fractions, one of optically clear quartz apparently free of inclusions, a second of clear quartz with traces of dawsonite in a few chips, and a third rich in dawsonite. The analytical results were as follows:

\begin{tabular}{lr}
\hline $\begin{array}{l}\text { Optically clear quartz } \\
\text { Clear quartz with traces } \\
\text { of dawsonite in some ehips }\end{array}$ & $17 \mathrm{ppm} \mathrm{Al}$ \\
Dawsonite-rich quartz & $190 \mathrm{ppm} \mathrm{Al}$ \\
\hline
\end{tabular}

It is clear from these analyses that if the presence of dawsonite in this crystal were completely overlooked and it were assumed that all determined aluminum was in solid solution in the quartz, then erroneous temperature estimates would result in applying the curve of Dennen et al. (1970). Clear portions of this crystal would give temperatures in the vicinity of $90^{\circ} \mathrm{C}$ while the dawsonite-rich portions would register temperatures slightly in excess of $700^{\circ} \mathrm{C}$. Clochiatti and Touray (1971) raise a similar point in stressing the presence of aluminous vitreous and liquid inclusions in magmatic quartz and the difficulties these might create in attempting to apply the aluminum geothermometer. The present data underscore the need, as cited by Dennen and others (1970), for scrupulous care in the selection of inclusion-free material for the aluminum determinations. It would seem virtually impossible, employing the careful methods described by Blackburn and Dennen (1971), to miss the abundant inclusions present in the dawsonite-rich sample described above, but lesser quantities might be overlooked and still introduce error into the temperature estimates.

The spectrographic analyses of the Oriental mine quartz pose a more fundamental question with regard to the validity of the aluminum thermometer itself. At first thought, the presence of abundant dawsonite in primary fluid inclusions would seem to offer more than the usual assurance of quartz growth in an aluminum saturated environment and thus encourage application of the thermometer. If all of the aluminum (20 ppm) in the clearest quartz is assumed to be in solid solution then, as noted above, crystallization temperatures indicated by the curve of Dennen et al. (1970, Fig. 3) are about $90^{\circ} \mathrm{C}$. In contrast, the filling temperatures of primary inclusions in this same quartz are from 201 to $233^{\circ} \mathrm{C}$, and these must be regarded as minimum growth temperatures that are subject 
to upward correction for total pressure at the time of quartz deposition. If some of the determined aluminum were actually contained in dawsonite, this would only serve to enlarge the discrepancy. It is suggested that the published aluminum thermometer curve is in error at least below about $235^{\circ} \mathrm{C}$, and that the error arises from the treatment of fluid inclusion filling temperatures for samples of natural vein quartz upon which this part of the curve is based. Evidently, the filling temperatures were plotted without corrections for total pressure. The effect of such corrections would be to flatten the thermometer curve so that it would pass through higher than the published aluminum contents at all temperatures below about $235^{\circ} \mathrm{C}$ (see Dennen et al., 1970, Fig. 3). In order to accomodate the combination of high filling temperatures and low aluminum contents in clear quartz of the Oriental mine, a rather drastic revision of the curve would. be required.

\section{Origin of Dawsonite in Fluid Inclusions}

The origin of dawsonite as a daughter mineral is somewhat obscured by questions of its metastability during both artificial heating tests and its precipitation in the natural cooling process. Dawsonite of the Oriental mine shows no change whatever during filling temperature determinations, but this failure to re-dissolve could be attributed either to its initial formation above these temperatures or to its metastable persistence at the rapid heating rates involved. Dawsonite (?) in quartz of the Bolivian deposits shows a similar reluctance to dissolve when rapidly heated to the inclusion filling temperatures (in one case as high as $433^{\circ} \mathrm{C}$ ), but is completely dissolved when held at these same temperatures for 48 hours. The mineral might even dissolve at temperatures well below the filling point if given sufficient time and, in the absence of such long duration experiments, the temperature at which the dawsonite actually began to form in the cooling inclusion fluids remains unknown. From the complete lack of dawsonite as a normal vein or alteration mineral and even as microscopic solid inclusions (i.e., free of associated fluids) in the Oriental ores, it does seem clear that the hydrothermal fluids were originally undersaturated in dawsonite, and that a considerable degree of cooling was probably required before dawsonite finally began to precipitate in the trapped fluids.

The common occurrence of oligoclase $\left(A n_{10}\right)$ as a vein mineral and wallrock alteration produet in the Oriental mine indicates that the mineralizing fluids were at times saturated with respect to sodic plagioclase. It is curious, therefore, that these saturated fluids formed dawsonite rather than additional oligoclase after their entrapment and cooling in quartz. As noted above, a daughter crystal of oligoclase (?) was observed in one sample of quartz from the altered granite, but it is dawsonite that typically occupies the inclusions. As suggested to us by Dr. Eric J. Essene, this raises the interesting possibility that sodic plagioclase may give way to the pair dawsonite-quartz as the stable assemblage in the inclusions at low temperature via the reaction:

$$
\begin{aligned}
\text { Quartz }+ \text { Dawsonite } & =\text { Albite } \\
3 \mathrm{SiO}_{2}+\mathrm{NaAlCO}_{3}(\mathrm{OH})_{2} & =\mathrm{NaAlSi}_{3} \mathrm{O}_{8}+\mathrm{H}_{2} \mathrm{O}+\mathrm{CO}_{2} .
\end{aligned}
$$


The similar reaction for oligoclase which actually occurs at the Oriental mine would be:

Quartz + Dawsonite = Oligoclase

$29 \mathrm{SiO}_{2}+11 \mathrm{NaAlCO}_{3}(\mathrm{OH})_{2}+\mathrm{Ca}^{++}=\mathrm{Na}_{9} \mathrm{CaAl}_{11} \mathrm{Si}_{29} \mathrm{O}_{80}+11 \mathrm{H}_{2} \mathrm{O}+11 \mathrm{CO}_{2}+2 \mathrm{Na}^{+}$.

In the absence of any experimental data on these reactions, it is uncertain whether the observed dawsonite is a metastable daughter mineral in inclusions that should have precipitated some sodic plagioclase, or that dawsonite-quartz is indeed the stable pair. Both of these possibilities are of general petrologic interest and the reactions given merit future laboratory investigation.

The mere presence of dawsonite in inclusions offers unambiguous evidence of dissolved aluminum in the original vein fluid, and the minimum quantity of that aluminum might be calculated from the observed volume of the dawsonite. Unfortunately, the true volume of the radiating dawsonite aggregates is impossible to measure. In most inclusions, the mineral appears to fill at least $10 \%$, and commonly more than $20 \%$, of the total inclusion volume, but the aggregates are not compact and the true volumes are probably much smaller. If, for the inclusions shown in Fig. 1, the volume of dawsonite is conservatively estimated. as only 2 volume percent, this would require at least $9800 \mathrm{ppm}$ or about 1 weight percent dissolved aluminum in the original ore fluid. Some of the aluminous wallrocks (amphibolite and feldspathic quartzite) of the Oriental mine have undergone extensive to complete replacement by ankerite close to the veins, and they provided a nearby source for these substantial quantities of dissolved aluminum.

The solubility relations of dawsonite at elevated temperatures and pressures are unknown, but if they follow the familiar pattern of other carbonates (Holland, 1967), then solution of the mineral is favored by increasing acidity, increasing dissolved $\mathrm{CO}_{2}$ and decreasing temperature. In this case, cooling of inclusion fluids would increase the solubility of dawsonite and the mineral could not precipitate if temperature per se were the only controlling variable. It is probably the continual and visible transfer of dissolved $\mathrm{CO}_{2}$ from the water-rich inclusion liquid into the vapor and liquid $\mathrm{CO}_{2}$ phases that is responsible for the crystallization of dawsonite. While this transfer of $\mathrm{CO}_{2}$ is caused by cooling, its effect on the solubility of dawsonite would be opposite to that of temperature per se.

The general rarity of dawsonite as a vein mineral or alteration product is probably due to its high solubility under normal hydrothermal conditions. The acidity and dissolved carbon dioxide contents of most vein fluids are probably too high at the time of mineralization to allow this mineral to precipitate. The few reported occurrences of dawsonite in low temperature, hydrothermal deposits (Palache and others, 1951) may represent unusual situations in which several factors favoring dawsonite (loss of dissolved $\mathrm{CO}_{2}$ due to fluid cooling or boiling, sharp reduction in fluid acidity due to wallrock reaction, high dissolved sodium and aluminum concentrations) operated in some combination. Common occurrence of dawsonite as a daughter mineral in hydrothermal fluid inclusions may seem to contradict its general rarity as a normal vein or alteration mineral but, in this respect, its behavior is similar to other soluble compounds like halite which 
is almost unknown as a vein mineral, yet extremely common as a daughter salt in ore deposits.

Acknowledgements. We are grateful to Dr. William H. Dennen of the Graduate School, University of Kentucky, for his spectrographic analysis of dawsonite-bearing quartz. Several friends in the Department of Geology and Mineralogy at The University of Michigan, particularly Drs. Eric J. Essene and Donald R. Peacor, contributed valuable suggestions in the course of our work. Equipment employed in this study was provided by the National Science Foundation under Grant GP 1061.

\section{References}

Blackburn, W. H., Dennen, W. H.: Reply to the discussion on "Aluminum in quartz as a geothermometer". Contr. Mineral. and Petrol. 30, 359-360 (1971).

Clocchiatti, R., Touray, J. C.: Remarques sur la note "Aluminum in quartz as a geothermometer". Contr. Mineral. and Pefrol. 30, 356-358 (1971).

Coveney, R. M.: Quartz as a geobarometer. Univ. of Michigan M. S. Thesis, Department of Geology and Mineralogy (1968).

- Gold mineralization at the Oriental mine, Alleghany, California. Univ. of Michigan, PhD Thesis, Department of Geology and Mineralogy (in Preparation, 1971).

Dennen. W. H., Blackburm, W. H.: Aluminum in quartz as a geothermometer. Contr. Mineral. and Petrol. 27, 332-342 (1970).

Ferguson, H. G., Gannet, R. W.: Gold quartz veins of the Alleghany district, California. U. S. Geol. Surv. Profess. Papers. 172 (1932).

Goldberry, R., Loughnan, F. C.: Dawsonite and nordstrandite in the Permian Berry Formation of the Sydney Basin, New South Wales. Am. Mineralogist 55, 477-490 (1970).

Harrington, B. J.: Notes on dawsonite, a new carbonate. Canadian Naturalist 7, 305-309 (1874).

Hay, P. L.: Zeolitio weathering in Olduvai Gorge, Tanganyika. Bull. Geol. Soc. Am. 74, 1281-1286 (1963).

Holland, H. D.: Gangue minerals in hydrothermal deposits. In: Geochemistry of hydrotherma ore deposits. New York: Holt, Rinehart and Winston 1967.

Kelly, W. C., Turneaure, F. S.: Mineralogy, paragenesis and thermometry of the tin and tungsten deposits of the Eastern Andes, Bolivia. Econ. Geol. 65, 609-680 (1970).

Kennedy, G. C.: Pressure-volume-temperature relations in $\mathrm{CO}_{2}$ at elevated temperatures and pressures. Am. J. Sci. 252, 225-241 (1954).

Loughnan, F. C., See, G. T.: Dawsonite in the Greta Coal Measures at Muswellbrook, New South Wales. Am. Mineralogist 52, 1216-1219 (1967).

Mandarino, J. A., Harris, D. C.: New Canadian mineral occurrences: I, eucryptite, pollucite, rozenite, epsomite, dawsonite, fairchildite and butschliite: Can. Mineralogist 8, 378-382 (1965).

Michelle, V. de, Minutti, L., Scaini, G.: Considerazioni sulla dawsonite di aleune nuove località. Atti. Soc. Ital. Sci. Naturali e Museo Curio di Storia Naturale di Milano CIV, 383-391 (1965).

Milton, C., Eugster, H. P.: Mineral assemblages of the Green River Formation in Researches in geochemistry. New York: John Wiley \& Sons 1959.

Palache, C., Berman, H., Frondel, C.: System of mineralogy, 7 ed., vol. 2. New York: John Wiley \& Sons 1951.

Smith, J. W., Milton, C.: Dawsonite in the Green River Formation of Colorado. Econ. Geol. 61, 1029-1042 (1966).

Professor Dr. W. C. Kelly

Department of Geology

The University of Michigan

Ann Arbor, Michigan 48104, U.S.A. 